\title{
Cyprinid herpesvirus 3: an interesting virus for applied and fundamental research
}

\author{
Krzysztof Rakus, Ping Ouyang, Maxime Boutier, Maygane Ronsmans, Anca Reschner, Catherine Vancsok, \\ Joanna Jazowiecka-Rakus and Alain Vanderplasschen*
}

\begin{abstract}
Cyprinid herpesvirus 3 (CyHV-3), a member of the family Alloherpesviridae is the causative agent of a lethal, highly contagious and notifiable disease in common and koi carp. The economic importance of common and koi carp industries together with the rapid spread of CyHV-3 worldwide, explain why this virus became soon after its isolation in the 1990s a subject of applied research. In addition to its economic importance, an increasing number of fundamental studies demonstrated that CyHV-3 is an original and interesting subject for fundamental research. In this review, we summarized recent advances in CyHV-3 research with a special interest for studies related to
\end{abstract} host-virus interactions.

\section{Table of contents}

1. Introduction

2. Characterization of $\mathrm{CyHV}-3$

2.1 General description 2.1.1 Classification

2.1.2 Morphology

2.1.3 Genome

2.1.4 Genotypes

2.1.5 Proteome

2.2 In vitro replication

2.3 Temperature restriction

2.3.1 In vitro

2.3.2 In vivo

2.4 Geographical distribution

2.5 Presence of CyHV-3 in natural environment

3. Disease

3.1 Disease characteristics

3.1.1. Clinical signs

3.1.2. Histopathology

3.2 Host range and susceptibility

3.3 Pathogenesis

3.4 Transmission

3.5 Diagnosis

3.6 Vaccination

* Correspondence: a.vdplasschen@ulg.ac.be

Immunology-Vaccinology (B43b), Department of Infectious and Parasitic Diseases, Faculty of Veterinary Medicine, University of Liège, B-4000 Liège, Belgium

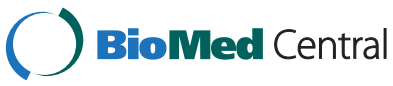

(C) 2013 Rakus et al.; licensee BioMed Central Ltd. This is an Open Access article distributed under the terms of the Creative Commons Attribution License (http://creativecommons.org/licenses/by/2.0), which permits unrestricted use, distribution, and reproduction in any medium, provided the original work is properly cited.
4. Host-pathogen interactions

4.1 Genetic resistance of carp strains to CyHV-3

4.2 Immune response of carp against CyHV-3

4.2.1 Interferon type I response

4.2.2 The role of CyHV-3 IL-10 homologue

5. Conclusions

6. Abbreviations

7. Competing interests

8. Authors' contributions

9. Acknowledgements

10. References

\section{Introduction}

The common carp (Cyprinus carpio) is one of the oldest cultivated fish species. In China, culture of carp dates back to at least the $5^{\text {th }}$ century $\mathrm{BC}$, whereas in Europe, carp farming began during the Roman Empire [1]. Nowadays, common carp is one of the most economically valuable species in aquaculture: $(i)$ it is one of the main cultivated fish for human consumption with a world production of 3.4 million tons per year [2]; (ii) it is produced and stocked into fishing areas for angling purpose; and (iii) its colorful, ornamental varieties (koi carp) grown for personal pleasure and competitive exhibitions represent probably the most expensive market of individual freshwater fish with some prize-winners sold for $10^{4}-10^{6}$ US dollars [3].

Herpesviruses infect a wide range of vertebrates and invertebrates [4]. However, the host-range of individual 
herpesvirus species is generally restricted revealing hostvirus co-evolution. In aquaculture, herpesvirus infections have been associated with mass mortality of different fish species causing severe economic losses [5-7]. In the late 1990s, a new highly contagious and virulent disease began to cause severe economic losses in both koi and common carp industries. Soon after its first known occurrences reported in Israel, USA, and Germany $[8,9]$, the disease was described in various countries worldwide. The rapid spread of the disease was attributed to international fish trade and to koi shows around the world [10]. The causative agent of the disease was initially called koi herpesvirus (KHV) because of its morphological resemblance to viruses of the order Herpesvirales [9]. The virus was subsequently called carp interstitial nephritis and gill necrosis virus (CNGV) because of the associated lesions [11]. Finally, on the basis of genome homology with previously described cyprinid herpesviruses the virus was renamed cyprinid herpesvirus 3 (CyHV-3) [12].

Because of its worldwide spread and the economic losses it caused, CyHV-3 became rapidly a notifiable disease and a subject of application oriented research. However, an increasing number of recent studies have demonstrated that it is also an interesting subject for fundamental research. In this review, we summarized recent advances in CyHV-3 research with a special interest for those related to host-virus interactions.

\section{Characterization of CyHV-3}

\subsection{General description}

\subsubsection{Classification}

CyHV-3 is a member of genus Cyprinivirus, family Alloherpesviridae, order Herpesvirales (Figure 1A) [13]. The Alloherpesviridae is a newly designated family which regroups herpesviruses infecting fish and amphibians [14]. It is divided into four genera: Cyprinivirus, Ictalurivirus, Salmonivirus, and Batrachovirus [13]. The genus Cyprinivirus contains viruses that infect common carp (Cyprinid herpesvirus 1 and 3; CyHV-1 and CyHV-3), goldfish (Cyprinid herpesvirus 2; CyHV-2) and freshwater eel (Anguillid herpesvirus 1; AngHV-1). Phylogenetic analyses revealed that the genus Cyprinivirus forms a clade distinct from the three other genera listed above (Figure 1B). Viruses of the Cyprinivirus genus possess the largest genomes (248-295 kb) in the order Herpesvirales.

\subsubsection{Morphology}

Like all members of the order Herpesvirales, CyHV-3 virions are composed of an icosahedral capsid containing the genome, a lipid envelope bearing viral glycoproteins and an amorphous layer of proteins termed tegument, which resides between the capsid and the envelope [15]. The diameter of CyHV-3 virions is 167-200 nm according to the infected cell type (Figure 2) [15]. Morphogenesis of
CyHV-3 is also characteristic of the order Herpesvirales, with assembly of the nucleocapsid and acquisition of the lipid envelope (derived from host cell trans-golgi membrane) that take place in the nucleus and the cytosol of the host cell, respectively $[9,15,16]$.

\subsubsection{Genome}

The genome of CyHV-3 is a $295 \mathrm{~kb}$, linear, double stranded DNA molecule consisting of a large central portion flanked by two $22 \mathrm{~kb}$ repeat regions, called the left and right repeats [18]. To date, this is the largest genome among all sequenced herpesviruses. The CyHV-3 genome has been cloned as a stable and infectious bacterial artificial chromosome (BAC), which can be used to produce CyHV-3 recombinants [19].

The CyHV-3 genome is predicted to contain 155 potential protein-coding open reading frames (ORFs), among which eight (ORF1-ORF8) are duplicated in terminal repeats [13]. Nine ORFs are characterized by the presence of introns [13]. CyHV-3 genome encodes five gene families: ORF2, tumor necrosis factor receptor (TNFR), ORF22, ORF25, and RING gene families [18]. The ORF25 family consists of 6 paralogous sequences (ORF25, ORF26, ORF27, ORF65, ORF148 and ORF149) encoding potential type 1 membrane glycoproteins. Independently of the viral strain sequences, ORF26 is described as a pseudogene; while ORF27 has been characterized as pseudogene in 2 out of 3 sequenced laboratory strains [18]. All nonfragmented members of this family (ORF25, ORF65, ORF148 and ORF149) are incorporated in mature virions, presumably in the envelope [20].

Interestingly, CyHV-3 genome encodes proteins potentially involved in immune evasion mechanisms such as, for example, G-protein coupled receptor (encoded by ORF16), TNFR homologues (encoded by ORF4 and ORF12) and an interleukine-10 (IL-10) homologue (encoded by ORF134) [18].

Among the family Alloherpesviridae, twelve ORFs (named core ORFs) are conserved in all sequenced viruses and were presumably inherited from a common ancestor [13]. The Cypriniviruses (CyHV-1, CyHV-2 and CyHV-3) possess 120 orthologous ORFs. Twenty one ORFs are unique to CyHV-3, including ORF134 encoding an IL-10 homolog [13]. The recently described second IL-10 homo$\log$ in the family Alloherpesviridae encoded by AngHV-1 does not seem to be an orthologue of the CyHV-3 ORF134 [21]. CyHV-3 shares 40 orthologous ORFs with AngHV-1 although the total number of ORFs shared by all CyHVs with AngHV-1 is estimated to be 55 [13]. This supports the phylogenetic conclusion that among the genus Cyprinivirus, CyHVs are more closely related to each other than to other members of the family Alloherpesviridae [14]. Interestingly, CyHV-3 also encodes genes with closest relatives in viral families such as Poxviridae and Iridoviridae $[18,22]$. 


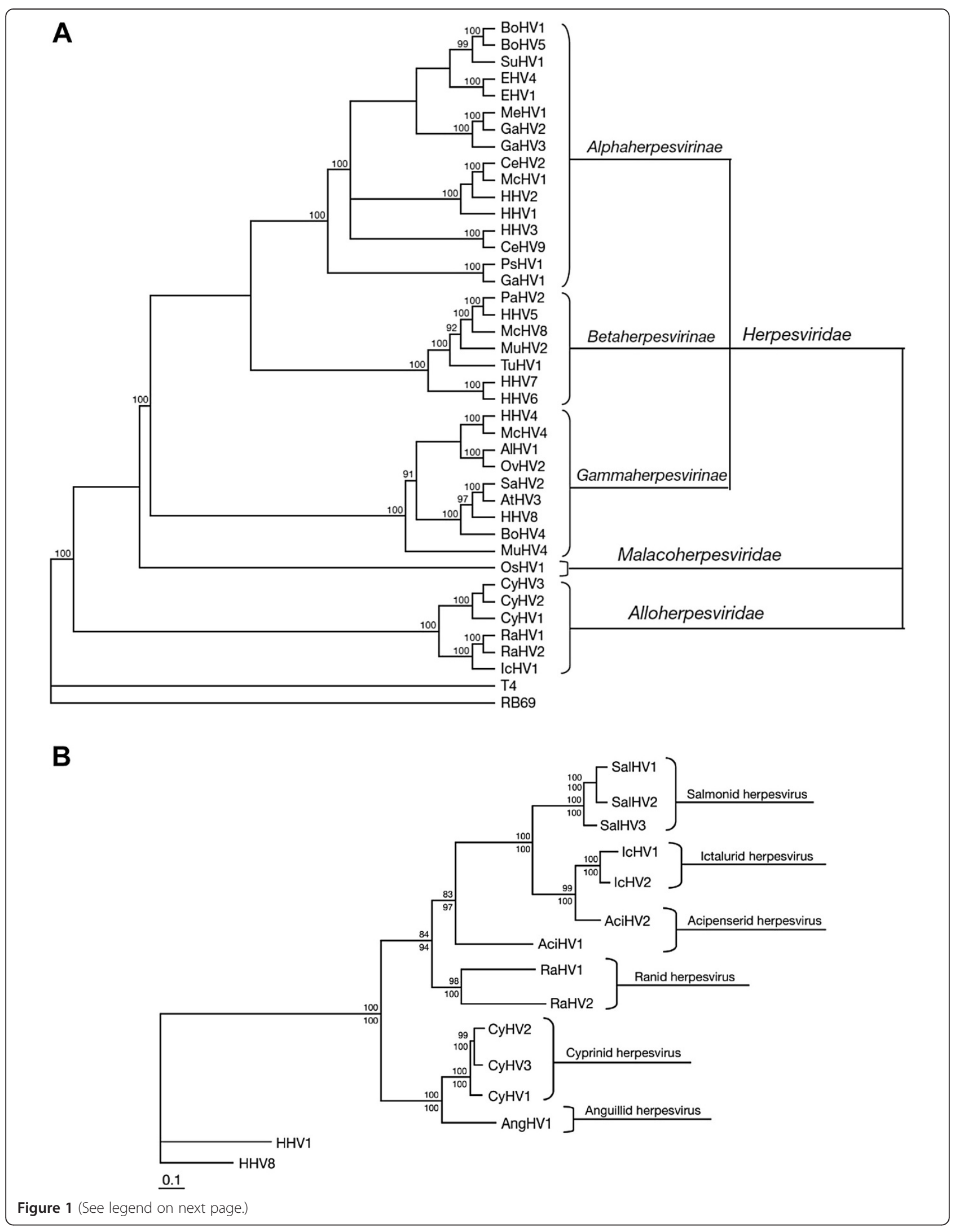


(See figure on previous page.)

Figure 1 Phylogeny of the order Herpesvirales and the Alloherpesviridae family. (A) Cladogram depicting relationships among viruses in the order Herpesvirales, based on the conserved regions of the terminase gene. The Bayesian maximum likelihood tree was rooted using bacteriophages T4 and RB69. Numbers at each node represent the posterior probabilities (values $>90$ are shown) of the Bayesian analysis. (B) Phylogenetic tree depicting the evolution of fish and amphibian herpesviruses, based on sequences of the DNA polymerase and terminase genes. The maximum likelihood tree was rooted with two mammalian herpesviruses (HHV-1 and HHV-8). Maximum likelihood values (> 80 are shown) and Bayesian values (> 90 are shown) are indicated above and below each node, respectively. Branch lengths are based on the number of inferred substitutions, as indicated by the scale bar. AlHV-1: alcelaphine herpesvirus 1; AtHV-3: ateline herpesvirus 3; BoHV-1, -4 , -5 : bovine herpesvirus 1, 4, 5; CeHV-2, -9: cercopithecine herpesvirus 2, 9; CyHV-1, -2: cyprinid herpesvirus 1, 2; EHV-1, -4: equid herpesvirus 1, 4; GaHV-1, -2, -3: gallid herpesvirus 1, 2, 3; HHV-1, -2, -3, -4, -5, -6, -7, -8: human herpesvirus 1, 2, 3, 4, 5, 6, 7, 8; lcHV-1: ictalurid herpesvirus 1; McHV-1, -4, -8: macacine herpesvirus 1, 4, 8; MeHV-1: meleagrid herpesvirus 1; MuHV-2, -4: murid herpesvirus 2, 4; OsHV-1: ostreid herpesvirus 1; OvHV-2: ovine herpesvirus 2; PaHV-1: panine herpesvirus 1; PsHV-1: psittacid herpesvirus 1; RaHV-1, -2: ranid herpesvirus 1, 2; SaHV-2: saimiriine herpesvirus 2; SuHV-1: suid herpesvirus 1; TuHV-1: tupaiid herpesvirus 1. Reproduced with permission from Waltzek et al. [14].

\subsubsection{Genotypes}

Whole genome analysis of three CyHV-3 strains isolated in Israel (CyHV-3 I), Japan (CyHV-3 J) and United States (CyHV-3 U) revealed high sequence identity between the strains [18]. The relationships between these strains revealed that $U$ and I strains are more closely related to each other and form one lineage (U/I), whereas J strain is more distinct and forms a second lineage (J) [18]. The existence of genetic differences between European lineage (including $U$ and I genotypes) and Asian lineage (including J genotype) were later confirmed and suggests independent $\mathrm{CyHV}-3$ introductions in various geographical locations [23,24]. Furthermore, Kurita et al. demonstrated that the Asian lineage contains only two variants (A1 and A2) while the European lineage has seven variants (E1-E7) [24]. Recently, a new intermediate genetic lineage of $\mathrm{CyHV}-3$ including isolates from Indonesia has been suggested [25]. This hypothesis was

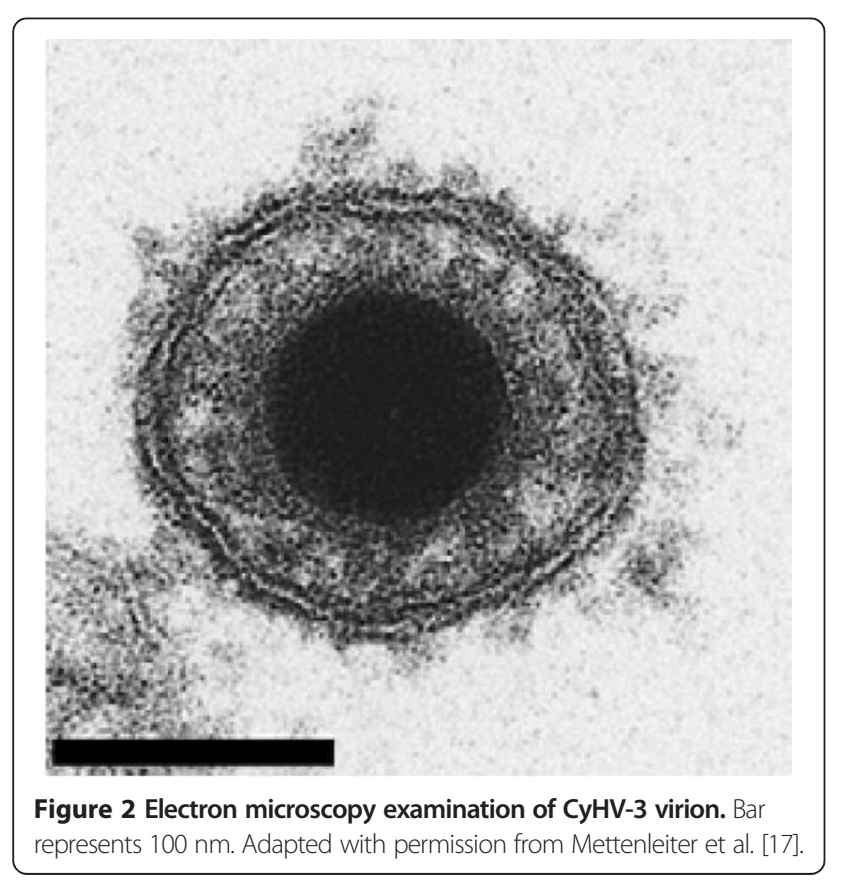

later supported by analyses of multi-locus variable number of tandem repeats (VNTR). These analyses also suggested that genetically distinct viral strains can coexist in a same location following various introduction events [26]. Although previous study described presence of both CyHV-3 lineages in Europe [23], an European genotype of CyHV-3 has only been revealed recently in East and Southeast Asia [27]. Recently, Han et al. described polymorphism in DNA sequences encoding three envelope glycoprotein genes (ORF25, ORF65, and ORF116) among CyHV-3 strains from different geographical origins [28].

\subsubsection{Proteome}

Different groups used mass spectrometry to identify CyHV-3 proteins and to study their interactions with cellular and viral proteins. The structural proteome of CyHV-3 was recently characterized by using liquid chromatography tandem mass spectrometry [20]. A total of 40 structural proteins, comprising 3 capsid, 13 envelope, 2 tegument, and 22 unclassified proteins, were described (Figure 3). The genome of CyHV-3 possesses 30 potential transmembrane-coding ORFs [18]. With the exception of ORF81, which encodes a type 3 membrane protein expressed on the CyHV-3 envelope, no CyHV-3 structural proteins have been studied [20,29]. ORF81 is thought to be one of the most immunogenic (major) membrane proteins of CyHV-3 [29]. Recently, Gotesman et al. using anti-CyHV-3 antibody-based purification coupled with mass spectrometry, identified 78 host proteins and five potential immunogenic viral proteins [30]. In another study, concentrated supernatant was produced from CyHV-3 infected CCB cultures and analyzed by 2D-LC MS/MS in order to identify CyHV-3 secretome. Five viral and 46 cellular proteins were detected [31]. CyHV-3 ORF12 and ORF134 encoding respectively a soluble TNFR homologue and an IL-10 homologue, were among the most abundant secreted viral proteins [31].

\subsection{In vitro replication}

CyHV-3 is widely cultivated in cell lines derived from common carp brain (CCB), gills (CCG) and fin (CaF-2) 


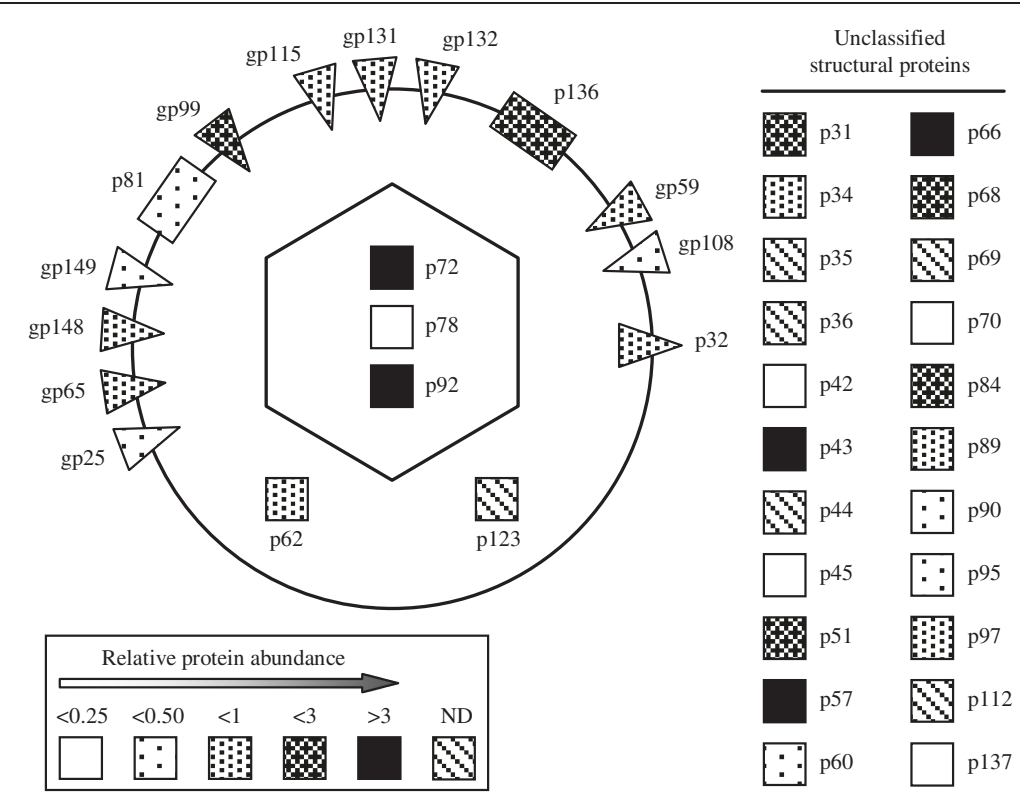

Figure 3 Schematic representation of CyHV-3 virion proteome. The viral composition of the envelope (circle), capsid (hexagon) and tegument is indicated. Membrane proteins of type 1,2 and 3 are represented by triangles pointed inside, triangles pointed outside and rectangles, respectively. Other proteins are shown as squares. The different fillings indicate the relative abundance of proteins based on their emPAl $(<0.25,<0.50,<1,<3$ and $>3)$. p: protein, gp: glycoprotein, ND: no data. Reproduced with permission from Michel et al. [20].

[32,33]. Permissive cell lines have also been derived from koi fin: KF-1 [9], KFC [11], KCF-1 [34], NGF-2 and NGF-3 [16]. Non-carp cell lines, such as silver carp fin (Tol/FL) and goldfish fin $(\mathrm{Au})$ were also described as permissive to $\mathrm{CyHV}-3$ [35]. Oh et al. reported the expression of cytopathic effect (CPE) in cell line from fathead minnow (FHM) after inoculation with CyHV-3 [36], but this observation was not confirmed by other studies $[9,35]$.

In vitro study showed that all annotated CyHV-3 ORFs are transcribed during CyHV-3 replication [37]. Transcription of CyHV-3 genes starts as early as $1 \mathrm{~h}$ post-infection and viral DNA synthesis initiates as early as $4-8 \mathrm{~h}$ postinfection [37]. Similar to all other herpesviruses, most of CyHV-3 ORF transcripts can be classified into three temporal kinetic classes: immediate early (IE; $n=15$ ORFs), early (E; $n=111$ ORFs) and late (L; $n=22$ ORFs). Seven ORFs are unclassified [37]. Fuchs et al. demonstrated that CyHV-3 ORFs that encode for three enzymes implicated in nucleotide metabolisms: thymidine kinase (ORF55), dUTPase (ORF123) and ribonucleotide reductase (ORF141) are nonessential for virus replication in vitro [38].

\subsection{Temperature restriction}

Water temperature is one of the major environmental factors that influences the onset and severity of viral infection in fish [39]. This statement certainly applies to CyHV-3 as temperature was shown to affect drastically both viral replication in vitro and $\mathrm{CyHV}-3$ disease in vivo.

\subsubsection{In vitro}

CyHV-3 replication in cell culture is restricted by temperature. Optimal viral growth in KF-1 cell line was observed at temperatures between $15{ }^{\circ} \mathrm{C}$ and $25{ }^{\circ} \mathrm{C}$. Virus propagation and virus gene transcription are gradually turned off when cells are moved from permissive temperature to the non-permissive temperature of $30{ }^{\circ} \mathrm{C}$ $[40,41]$. However, infected cells maintained for 30 days at $30{ }^{\circ} \mathrm{C}$ preserve infectious virus, as demonstrated by viral replication when the cells are returned to permissive temperatures [40].

\subsubsection{In vivo}

CyHV-3 disease occurs naturally when water temperature is between $18{ }^{\circ} \mathrm{C}$ and $28{ }^{\circ} \mathrm{C}$. Several studies demonstrated that transfer of recently infected fish (between 1 and 5 days post-infection (dpi)) to non-permissive low $\left(\leq 13{ }^{\circ} \mathrm{C}\right)$ or high temperatures $\left(>30{ }^{\circ} \mathrm{C}\right)$ significantly reduces the mortality [11,42-44]. Water temperature was also shown to affect the onset of mortality: the first mortalities occurred between 5-8 and 14-21 dpi when the fish were kept between $23-28{ }^{\circ} \mathrm{C}$ and $16-18{ }^{\circ} \mathrm{C}$, respectively [42,45].

\subsection{Geographical distribution}

CyHV-3 was first isolated from infected koi originating from Israel and USA in 2000 [9]. Soon after, outbreaks 
of CyHV-3 occurred in many countries in Europe, Asia and Africa [10,22]. Currently, only South America, Australia and northern Africa seem to be free of CyHV-3. The global and rapid spread of the virus is thought to be mainly due to the international trading of common and koi carp, but also to koi shows.

\subsection{Presence of CyHV-3 in natural environment}

In addition to its economic impact on common and koi carp industries, CyHV-3 has also a negative environmental impact by affecting wild populations of carp. In 2003, the first outbreak of CyHV-3 disease among wild carp occurred in the Yoshi river in Japan [46]. The virus then spread among several freshwater systems and caused mass mortalities in wild carp populations. In Lake Biwa, about $70 \%$ of carp population (more than 100000 fish) died due to CyHV-3 infection in 2004 [46]. Mass mortalities of wild carp have been also described in angling waters in UK in 2003 [47], in New York and South Carolina, USA in 2004 [48,49] and in Kawartha Lakes region, Ontario, Canada in 2007 [50]. The monitoring of the distribution of CyHV-3 in rivers and lakes in Japan demonstrated that it can persist in the wild carp populations and can be subsequently transmitted to naïve fish $[46,51,52]$. Studies performed in habitats with CyHV-3 history suggested that sediments [53] and aquatic invertebrates feeding by water filtration could represent potential reservoirs of CyHV-3 [54]. Moreover the viral DNA could be detected in water not only during the outbreak of the disease but also for at least 3 months after the end of mass mortality [51]. However, it has to be noted that these studies relied on the detection of viral genome and not $\mathrm{CyHV}-3$ infectivity. Consequently further studies are required to determine whether these potential reservoirs of infectious virus could play a role in CyHV-3 epidemiology.

\section{Disease}

\subsection{Disease characteristics}

CyHV-3 disease is seasonal, occurring when water temperature is between $18{ }^{\circ} \mathrm{C}$ and $28{ }^{\circ} \mathrm{C}$. It is restricted to common and koi carp and their hybrids with other species [55]. It is highly contagious and extremely virulent with mortality rate that can reach 80 to $100 \%$. Fish infected with CyHV-3 by immersion, injection or oral route and kept at $23-28{ }^{\circ} \mathrm{C}$ die between 5 and $22 \mathrm{dpi}$ with a peak of mortality between 8 and 12 dpi [9,56,57]. Gilad et al. suggested that loss of osmoregulation of the gills, gut and kidney contributes to mortality during acute infection with CyHV-3 [42]. Furthermore, CyHV-3 infected fish are more susceptible to secondary infections by bacterial, parasitic or fungal pathogens which may cause further mortality within the population.

\subsubsection{Clinical signs}

The first clinical signs appear at 2-3 dpi. Fish become lethargic, lie at the bottom of the tank with the dorsal fin folded and exhibit loss of appetite. In ponds, infected fish are usually gathering close to the water inlet or sides of the pond and gasp at the surface of water. Gill necrosis coupled with extensive discoloration and increased mucus secretion appear as early as $3 \mathrm{dpi}$. Depending on the stage of the infection, the skin exhibits different clinical signs, such as hyperemia, particularly at the base of the fins and on the abdomen; pale, irregular patches on the skin associated with mucus hypersecretion at the beginning of infection; peeling away of dead epithelium and lack of mucus cover in the later stage of infection; appearance of epidermis surface with a sandpaper-like texture; and herpetic lesions (Figure 4). In addition, fin erosion and bilateral enophthalmia (sunken eyes) are observed in the later stages of infection. Some fish show neurologic signs in the final stage of disease, when they become disoriented and lose equilibrium [9,10,58].

\subsubsection{Histopathology}

The most important histopathological changes are observed in the gills. They involve erosion of primary lamellae, fusion of secondary lamellae and adhesion of gill filaments [58,59]. Gills also exhibit hyperplasia, hypertrophy and/or nuclear degeneration of branchial epithelium and congestion of the blood vessels in the gill arch $[15,59]$. Severe inflammation and gill necrosis resulting in the complete loss of lamellae can also be observed $[31,59]$. In the kidney, the hematopoietic cells are the most affected ones [15]. However, a weak peritubular inflammatory infiltrate is evident in kidney as early as 2 dpi and increases with time. It is accompanied by blood vessel congestion and degeneration of the tubular epithelium in many nephrons [59]. In the spleen and liver, the most obviously infected cells are splenocytes and hepatocytes, respectively [15]. In the liver, mild inflammatory infiltrates are observed mainly in the parenchyma [59]. In the brain, focal meningeal and parameningeal inflammation is observed [59]. Analysis of brain from fish that showed clear neurologic signs revealed congestion of capillaries and small veins associated with edematous dissociation of nerve fibers in the valvula cerebelli and medulla oblongata [15]. In the skin, the number of goblet cells is reduced by $50 \%$ in infected fish. Furthermore, the goblet cells appeared mostly slim and slender which suggests that mucus was released and had not been replenished. In addition, erosion of skin epidermis is frequently observed [60].

\subsection{Host range and susceptibility}

CyHV-3 causes a symptomatic disease only in common and koi carp. Hybrids of koi $\times$ goldfish and koi $\times$ crucian 

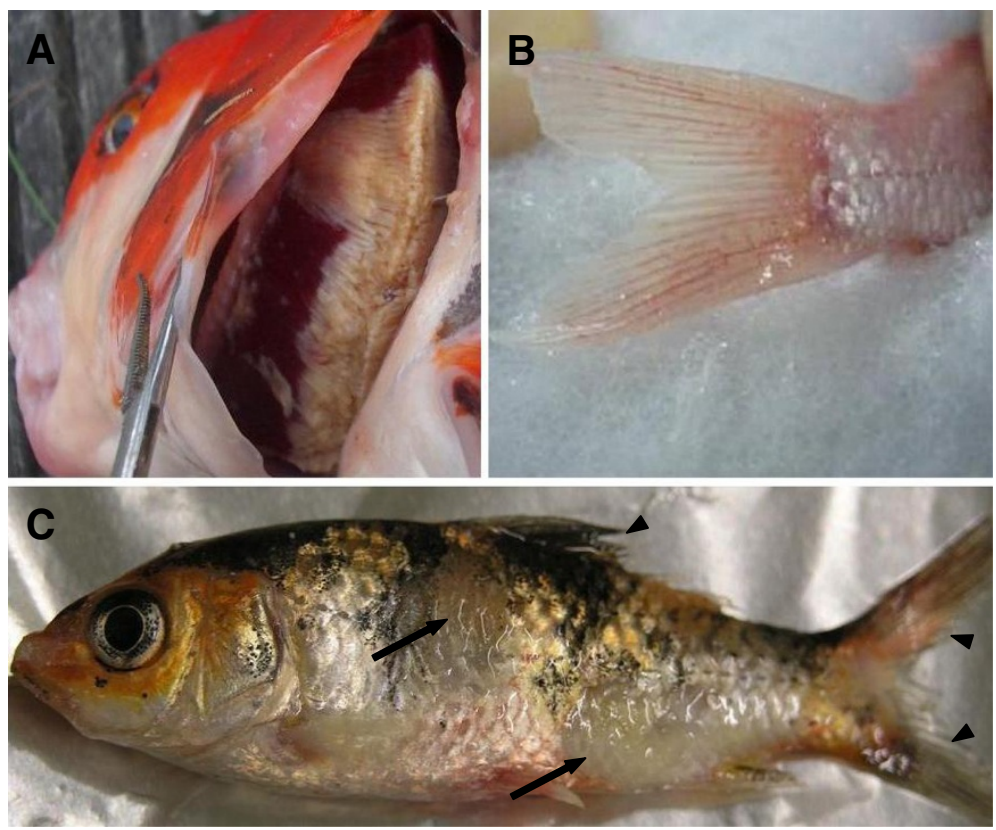

Figure 4 Some of the clinical signs observed during CyHV-3 infection. (A) Severe gill necrosis. (B) Hyperemia at the base of the caudal fin. (C) Herpetic skin lesions on the body (arrows) and fin erosion (arrowheads). Reproduced with permission from Michel et al. [22].

carp are also affected by CyHV-3 disease, with mortality rate of $35 \%$ and $91 \%$, respectively [55]. Common carp $\times$ goldfish hybrids have also been reported to show some susceptibility to CyHV-3 infection; however, the mortality rate observed was rather limited (5\%) [61]. PCR detection of CyHV-3 performed on cyprinid and noncyprinid fish species, but also on freshwater mussels and crustaceans, suggested that these species could act as reservoirs of the virus (Table 1) [54,62-67]. Cohabitation experiments suggest that some of these fish species (goldfish, tench, vimba, common bream, common roach, European perch, ruffe, gudgeon, rudd, northern pike, silver carp and grass carp) can carry CyHV-3 asymptomatically and transmit it to naïve carp [64,65,68-70]. Consistent with this observation, in vitro studies showed that CyHV-3 can replicate and cause CPE in cell cultures derived not only from common and koi carp but also from silver carp and goldfish [35]. Recent studies provided increasing evidence that CyHV-3 can infect goldfish asymptomatically $[68,69]$. Finally, the World Organisation for Animal Health (OIE) listed four CyHV-3 susceptible species (Cyprinus carpio and its hybrids, goldfish, Russian sturgeon and Atlantic sturgeon) and two potential susceptible species (grass carp and ide) [71].

Carp of all ages, from juveniles upwards, are affected by CyHV-3, but younger fish (1-3 months, 2.5-6 g) seem to be more susceptible to infection than mature fish (1 year, $\approx 230 \mathrm{~g}$ ) [58]. Ito et al. suggested that carp larvae are not susceptible to CyHV-3 since larvae (3 days posthatching) infected with virus showed no mortality whereas most of the carp juveniles ( $>13$ days posthatching) died after infection [72]. However, recent study using CyHV-3 recombinant strain expressing luciferase (LUC) as a reporter gene, demonstrates that carp larvae are sensitive and permissive to CyHV-3 infection immediately after hatching and that their sensitivity increases with the developmental stages [73].

\subsection{Pathogenesis}

In early reports, it has been suggested that CyHV-3 may enter the host through infection of the gills based on detection of viral particles and viral genome in this organ as early as 1-2 dpi [42,59]. However, more recent studies using in vivo bioluminescent imaging system demonstrated that according to epidemiological conditions CyHV-3 can enter carp either by skin (immersion in infectious water) or pharyngeal periodontal mucosa infection (ingestion of infectious materials) (Figure 5) [57,74]. The epidermis of teleost fish is a living stratified squamous epithelium that is capable of mitotic division at all levels (even the outermost squamous layer). The scales are dermal structures and consequently are covered by the epidermis [74]. Removal of skin mucus and epidermal lesions facilitates the entry of virus into the host (Figure 6) [75]. After initial replication in the epidermis [74] the virus is spreading rapidly in infected fish as indicated by detection of CyHV-3 DNA in almost all internal tissues as early as $24 \mathrm{~h}$ post-infection [42]. The tropism of CyHV-3 for white blood cells most probably explains such a rapid spread of the virus within the body 
Table 1 Organisms tested for CyHV-3 infection.

\begin{tabular}{|c|c|c|c|c|}
\hline \multirow[t]{2}{*}{ Common name (species) } & \multicolumn{3}{|c|}{ Detection of CyHV-3 } & \multirow{2}{*}{$\begin{array}{l}\text { Detection of CyHV-3 genome in } \\
\text { naïve carp after cohabitation }\end{array}$} \\
\hline & DNA & Transcript & Antigen & \\
\hline \multicolumn{5}{|l|}{ Vertebrates } \\
\hline \multicolumn{5}{|l|}{ Cyprinidae } \\
\hline Goldfish (Carassius auratus) & Yes $[62,68-70]$ & Yes [68] & Yes [69] & Yes [68-70] \\
\hline Ide (Leuciscus idus) & Yes $[62,63]$ & NT & NT & NT \\
\hline Grass carp (Ctenopharyngodon idella) & Yes $[62,64,70]$ & NT & NT & Yes $[64,70]$ \\
\hline Silver carp (Hypophthalmichthys molitrix) & Yes $[64,70]$ & NT & NT & Yes $[64,70]$ \\
\hline Prussian carp (Carassius gibelio) & Yes $[64,70] /$ No $[65]$ & NT & NT & Yes [70]/No [65] \\
\hline Crucian carp (Carassius carassius) & Yes [64] & NT & NT & NT \\
\hline Tench (Tinca tinca) & Yes $[64,65,70]$ & NT & NT & Yes $[64,65,70]$ \\
\hline Vimba (Vimba vimba) & Yes $[63,64]$ & NT & NT & Yes [64] \\
\hline Common bream (Abramis brama) & Yes $[64,65]$ & NT & NT & Yes [64] \\
\hline Common roach (Rutilus rutilus) & Yes $[64,65]$ & NT & NT & Yes [64]/No [65] \\
\hline Common dace (Leuciscus leuciscus) & Yes $[64,65]$ & NT & NT & No [65] \\
\hline Gudgeon (Gobio gobio) & Yes $[64,65]$ & NT & NT & Yes [65] \\
\hline Rudd (Scardinius erythrophthalmus) & Yes [65] & NT & NT & Yes [65] \\
\hline European chub (Squalius cephalus) & Yes [64]/No [65] & NT & NT & NT \\
\hline Common barbel (Barbus barbus) & Yes [64] & NT & NT & NT \\
\hline Belica (Leucaspius delineatus) & Yes [64] & NT & NT & NT \\
\hline Common nase (Chondrostoma nasus) & Yes [64] & NT & NT & NT \\
\hline \multicolumn{5}{|l|}{ Acipenseridae } \\
\hline Russian sturgeon (Acipenser gueldenstaedtii) & Yes [66] & NT & NT & NT \\
\hline Atlantic sturgeon (Acipenser oxyrhynchus) & Yes [66] & NT & NT & NT \\
\hline \multicolumn{5}{|l|}{ Cobitidae } \\
\hline Spined loach (Cobitis taenia) & Yes [64] & NT & NT & NT \\
\hline \multicolumn{5}{|l|}{ Cottidae } \\
\hline European bullhead (Cottus gobio) & Yes [64] & NT & NT & NT \\
\hline \multicolumn{5}{|l|}{ Esocidae } \\
\hline Northern pike (Esox lucius) & Yes $[64,65]$ & NT & NT & Yes [65] \\
\hline \multicolumn{5}{|l|}{ Gasterosteidae } \\
\hline Three-spined stickleback (Gasterosteus aculeatus) & Yes [65] & NT & NT & No [65] \\
\hline \multicolumn{5}{|l|}{ Ictaluridae } \\
\hline Brown bullhead (Ameiurus nebulosus) & Yes [65] & NT & NT & No [65] \\
\hline \multicolumn{5}{|l|}{ Loricariidae } \\
\hline Ornamental catfish (Ancistrus sp.) & Yes [62] & NT & NT & NT \\
\hline \multicolumn{5}{|l|}{ Percidae } \\
\hline European perch (Perca fluviatilis) & Yes $[64,65]$ & NT & NT & Yes [64]/No [65] \\
\hline Ruffe (Gymnocephalus cernua) & Yes [64]/No [65] & NT & NT & Yes $[64,65]$ \\
\hline \multicolumn{5}{|l|}{ Invertebrates } \\
\hline Swan mussels (Anodonta cygnea) & Yes [54] & NT & NT & NT \\
\hline Scud (Gammarus pulex) & Yes [54] & NT & NT & NT \\
\hline
\end{tabular}

NT- not tested. 


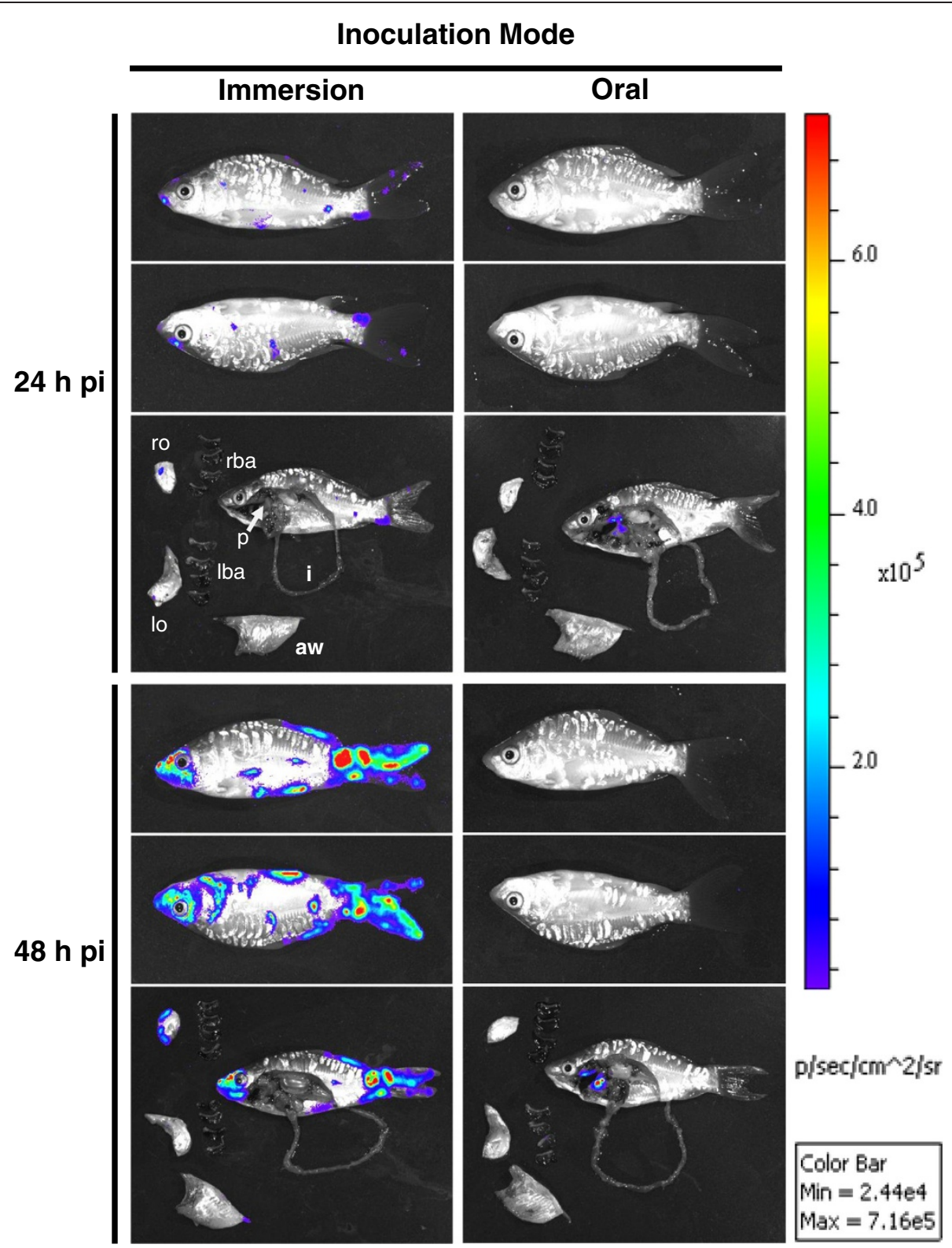

Figure 5 The portal of entry of CyHV-3 in carp analysed by bioluminescence imaging. Two groups of fish (mean weight $10 \mathrm{~g}$ ) were infected with a recombinant CyHV-3 strain expressing luciferase as a reporter gene either by bathing them in water containing the virus (Immersion, left column) or by feeding them with food pellets contaminated with the virus (Oral, right column). At the indicated time post-infection, six fish per group were analysed by bioluminescence IVIS. Each fish was analysed lying on its right and its left side. To analyze internal signals, fish were euthanized and dissected immediately after in vivo bioluminescence imaging. Dissected fish and isolated organs were analysed for ex vivo bioluminescence. The analysis of one fish is presented for each time point and inoculation mode. Pictures collected over the course of this experiment are presented with a standardized minimum and maximum threshold value for photon flux. rba, right branchial arches; Iba, left branchial arches; ro, right operculum; lo, left operculum; p, pharynx; aw, abdominal wall; i, intestine. Reproduced with permission from Fournier et al. [57].

[76]. Virus replication in organs such as the gills, skin and gut represents source of viral excretion into the water. Recently, pharyngeal periodontal mucosa has been shown to be the portal of entry of CyHV-3 after infection by the oral route using food pellets contaminated with the virus [57]. This model of inoculation led to the spreading of the infection to the various organs tested as well as resulted in clinical signs and mortality rate comparable to the infection by immersion [57].

All members of the family Herpesviridae exhibit 2 distinct phases in their biological cycle: lytic replication and latency. While lytic replication is associated with 


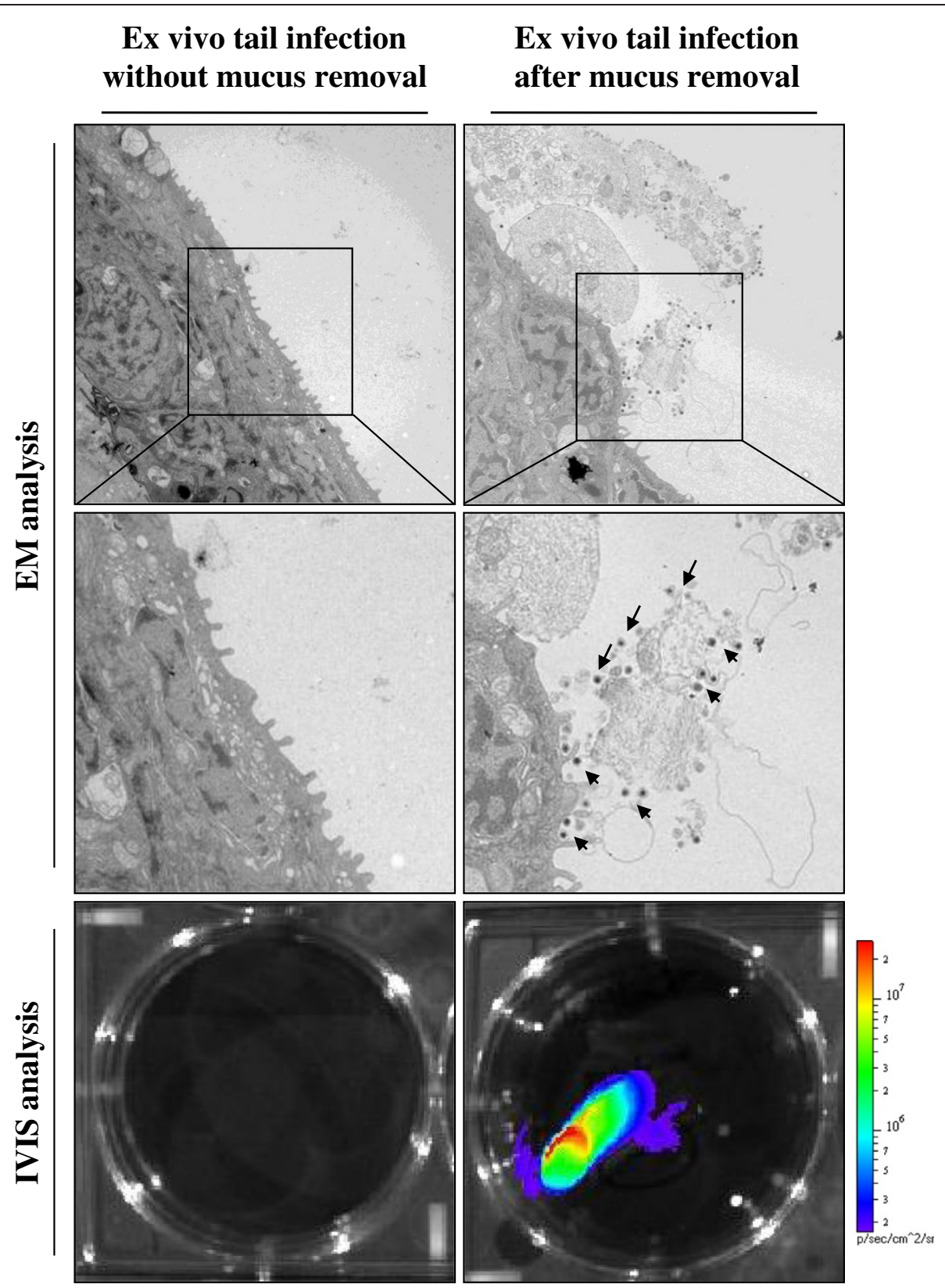

Figure 6 Effect of skin mucus removal on CyHV-3 binding to carp epidermal cells. Tail fin ventral lobes of carp were mock-treated or treated by rubbing with a soft tissue paper to remove epidermal mucus. Immediately after skin treatment, tail fin explants were harvested and inoculated ex vivo with a CyHV-3 recombinant strain expressing luciferase as a reporter gene ( $10^{6} \mathrm{PFU} / \mathrm{mL}$ of culture medium for $\left.2 \mathrm{~h}\right)$. At the end of the $2 \mathrm{~h}$ inoculation period, a fragment of the fin was collected and processed for electron microscopy examination (EM analysis). The arrows indicate CyHV-3 particles bound to cells or cell debris. Twenty-four hours post-inoculation, duplicate tail explant cultures were analyzed by bioluminescence imaging (lower panels). Reproduced with permission from Raj et al. [75].

production of viral particles, latency consists in the maintenance of the viral genome as a nonintegrated episome and the expression of very few viral genes and microRNAs. Upon reactivation, latency is replaced by lytic replication. Even if latency has not been demonstrated conclusively in members of the Alloherpesviridae family, an increasing number of evidences support the existence of latent phase. These evidences related to
CyHV-3 can be summarized as follows. (i) CyHV-3 DNA has been detected in the brain of fish that survived primary infection and showing no clinical signs at $64 \mathrm{dpi}$ [42], and even 1 year post-infection [77]. (ii) CyHV-3 persisted in the wild population of common carp for at least 2 years after initial outbreak [46]. (iii) Finally, St-Hilaire et al. described, in fish that survived the primary infection, the induction of $\mathrm{CyHV}-3$ reactivation 
by temperature stress several months after the initial exposure to the virus [43]. Increased level of viral DNA in gills without the appearance of disease symptoms has been detected after stress induced by netting fish that survived the primary infection and were kept at $20{ }^{\circ} \mathrm{C}$ for $81 \mathrm{dpi}$ [78]. Recent studies demonstrated that virus may become latent in white blood cells and other tissues, remains at very low copy numbers and can be reactivated by temperature stress $[76,79,80]$. To date, the temperaturedependent reactivation of the disease which resulted in mortality of naïve cohabitant fish has been described after transferring the fish maintained at a low temperature to the higher, permissive temperature [43,79]. These observations suggest that the temperature of the water could regulate the switch between latency and lytic replication and vice versa allowing the virus to persist in the host population throughout the seasons even when the temperature is non-permissive.

\subsection{Transmission}

To date, no evidence of CyHV-3 vertical transmission has been reported. Horizontal transmission of $\mathrm{CyHV}-3$ occurs either by direct transmission (fish to fish) or vector based transmissions. Direct transmission can be by skin to skin contact of infected carp or cyprinid and non-cyprinid fish species that can carry CyHV-3 asymptomatically $[64,68]$ against naïve carp; or by cannibalistic and necrophagous behaviors of the carp [22,57]. Several potential vectors could be involved in the vector based transmission of CyHV-3. Such vectors include fish droppings [81], plankton [82], aquatic invertebrates feeding by water filtration [54], piscivorous birds which could transfer the disease by moving sick fish from one pond to another [83], and finally the water being the major abiotic vector. Secretion of viral particles into the water either through shedding or together with sloughed epithelial cells has been documented [59]. Furthermore, the infectivity of CyHV-3 in water was shown to be conserved for at least $4 \mathrm{~h}$ [58], even if longer period could be observed depending on water composition (chemical and microbial) [84]. For example, the infectivity of CyHV-3 was drastically reduced after 3 days in environmental water, although it remained quite stable for more than 7 days in sterilized water [84].

\subsection{Diagnosis}

Various CyHV-3 diagnostic methods have been developed. They are based on the detection of infectious particles, viral DNA, transcripts, or antigens. Virus isolation from infected fish tissues in cell culture was the first method developed [9,11]. Although cell culture isolation is not as sensitive as PCR-based methods, it is the only technique able to detect infectious particles. Recently, Dong et al. isolated for the first time $\mathrm{CyHV}-3$ virus from diseased koi in mainland China using a newly developed cell line from caudal fin of koi [34]. A complete set of molecular techniques for detection of viral DNA fragments has been developed, such as DNA hybridization, PCR, nested PCR, one-tube semi-nested PCR, semiquantitative PCR, real-time TaqMan PCR, and loopmediated isothermal amplification [22]. CyHV-3 genome can also be detected and quantified in environmental water by real-time TaqMan PCR after viral concentration [85]. Recently, a mRNA-specific RT-PCR assay for detection of replicating $\mathrm{CyHV}-3$ in infected fish tissues and cell cultures has been described [86]. ELISA tests have been developed to detect specific anti-CyHV-3 antibodies in carp serum [22]. CyHV-3 has been also detected in tissues and touch imprints of organs from infected fish by immunohistochemistry and immunofluorescence assays, respectively [59]. Monoclonal antibodies against CyHV-3 ORF68 have been produced. They were proved to detect specifically CyHV-3 without cross-reaction against $\mathrm{CyHV}-1$ and $\mathrm{CyHV}-2$ [87]. Finally, a CyHV-3-detection kit (The FASTest ${ }^{\bullet}$ Koi HV kit) that allows the detection of CyHV-3 in gill swabs in just 15 min has been developed [88].

\subsection{Vaccination}

Soon after the identification of CyHV-3 as the causative agent of koi herepsvirus disease (KHVD), an original protocol was developed to induce a protective adaptive immune response in carp [11]. This approach exploited the fact that CyHV-3 induces fatal infections only when temperature is between $18{ }^{\circ} \mathrm{C}$ and $28{ }^{\circ} \mathrm{C}$. According to this protocol, healthy fingerlings are exposed to the virus by cohabitation with sick fish for 3-5 days at permissive temperature $\left(22{ }^{\circ} \mathrm{C}-23{ }^{\circ} \mathrm{C}\right)$. After that the fish are transferred to ponds for 25-30 days at non-permissive water temperature $\left(\approx 30{ }^{\circ} \mathrm{C}\right)$. Despite its ingenuity, this protocol has several disadvantages. (i) Fish that are "vaccinated" with this protocol become latently infected by a virulent strain and are therefore likely to represent a potential source of CyHV-3 outbreaks if they later cohabitate with naïve carp. ( $i$ ) The increase of water temperature to non-permissive is costly and correlated with increasing susceptibility of the fish to secondary infection. (iii) Finally, after this procedure only $60 \%$ of immunized fish proved to be resistant to a CyHV-3 challenge performed by cohabitation with infected fish [11].

Attenuated live vaccines appear to be the most appropriate for mass vaccination of carp. Live attenuated vaccine candidates have been produced by serial passages in cell culture of a pathogenic strain. A vaccine strain candidate was further attenuated by UV irradiation in order to increase random mutations throughout the genome $[11,89]$. Currently, a live attenuated vaccine developed using this approach has been manufactured by KoVax 
Ltd. (Jerusalem, Israel) and is available for immersion vaccination of common and koi carp in Israel [90]. Protection against CyHV-3 is associated with elevation of specific antibodies against the virus $[11,89]$. However, the duration of the protection conferred by the vaccine has not been established [90]. This vaccine has two major additional disadvantages: $(i)$ the determinism of the attenuation is unknown; and consequently, reversions to a pathogenic phenotype cannot be excluded; (ii) the attenuated strain retains residual virulence that could be lethal for a portion of the vaccinated fish [91], particularly for small/young fish.

An inactivated vaccine candidate was also described by Yasumoto et al. [92]. It consists of formalin-inactivated CyHV-3 trapped within a liposomal compartment. This vaccine can be used for oral immunization in fish food. Protection efficacy for carp was 70\% [92].

\section{Host-pathogen interactions}

\subsection{Genetic resistance of carp strains to CyHV-3}

Genetic differences in resistance to $\mathrm{CyHV}-3$ have been described among different carp strains and crossbreeds. Independent research groups demonstrated that resistance to $\mathrm{CyHV}-3$ can be significantly increased by crossing of domesticated carp strains with wild carp strains. Shapira et al. reported that the most resistant carp crossbreed in their study (60\% of survival) was that between the domesticated carp strain Dor-70 and the wild carp strain Sassan [93]. In comparison the survival rate of domesticated carp strains Našice and Dor-70 as well as their crossbreed was much lower (8\%, 27\% and 17.7\%, respectively) [93]. Recently, Piačková et al. demonstrated that most of Czech strains and crossbreeds which are genetically related to wild Amur carp were significantly more resistant to CyHV-3 infection than strains with no relation to Amur carp [94]. Carp genetic resistance to CyHV-3 has been investigated using 96 carp families derived from diallelic crossing of two wild carp strains (Amur and Duna) and two domesticated Hungarian strains (Tat and HAKI 15) [95]. This study demonstrated that crossing with wild carp strains may result in higher resistance to CyHV-3. However, individual parents of the strains are also important since many of the families derived from the wild strains did not exhibit significantly higher resistance [95]. Recently, resistance to CyHV-3 has been also linked to the polymorphism of the MHC class II $B$ genes [56] and carp IL-10 gene [96]. These findings support the hypothesis that the outcome of the disease can be controlled in some extent by genetic factors of the host, and consequently, that selection of resistant carp breeders is one of potential ways to reduce the negative impact of $\mathrm{CyHV}-3$ on carp aquaculture.

\subsection{Immune response of carp against CyHV-3}

Knowledge on the immune mechanisms and immunological traits that can correlate with disease resistance in fish as well as on the immune evasion mechanisms expressed by CyHV-3, is essential for the development of prophylactic strategies (such as vaccination) as well as for the development of more resistant strains by the use of molecular marker assisted selection. The information related to these topics are summarized in this section.

Perelberg et al. studied the kinetic of anti-CyHV-3 antibody expression in the serum of carp infected at different temperatures [91]. In fish that were infected and maintained at $24{ }^{\circ} \mathrm{C}$, antibody titers began to rise at $10 \mathrm{dpi}$ and reached a peak around 20-40 dpi. It was shown that protection against $\mathrm{CyHV}-3$ is proportional to the titer of specific antibodies produced during the primary infection. The level of antibodies decreased in the absence of antigenic re-exposure. At $280 \mathrm{dpi}$, the titer of anti-CyHV-3 antibodies of infected fish was only slightly higher or comparable to that of unexposed fish. Nevertheless, immunized fish, even those in which antibodies were no longer detectable were resistant to a lethal challenge; possibly because of the subsequent rapid response of $\mathrm{B}$ and $\mathrm{T}$ memory cells to antigen re-stimulation [91].

Recently, a transcriptomic study uncovered the wide array of immune-related genes involved in the antiCyHV-3 immune response of carp [97]. The response of two carp lines with different resistance to CyHV-3 has been studied using DNA microarray and real-time PCR. Significantly higher expression of several immunerelated genes including number of those which are involved in pathogen recognition, complement activation, MHC class I-restricted antigen presentation and development of adaptive mucosal immunity was noted in more resistant carp line. Further real-time PCR based analyses provided evidence for higher activation of $\mathrm{CD}^{+}$ $\mathrm{T}$ cells in the more resistant carp line. Thus, differences in resistance to $\mathrm{CyHV}-3$ can be correlated with differentially expressed immune-related genes [97].

The anti-CyHV-3 immune response has been studied in the skin and the intestine of common carp [60,98]. These studies revealed an up-regulation of pro-inflamatory cytokine IL-1 $\beta$, the inducible nitric oxide synthase (iNOS) and activation of interferon class I pathways [60,98]. In skin, CyHV-3 infection leads to down-regulation of genes encoding several important components of the skin-mucosal barrier, including antimicrobial peptides (beta defensing 1 and 2), mucin $5 \mathrm{~B}$, and tight junction proteins (claudin 23 and 30 ). This probably contributes to changes in the skin bacterial flora and subsequent development of secondary bacterial infections [60]. Raj et al. demonstrated that skin mucus also acts as an innate immune barrier and inhibits CyHV-3 binding to epidermal cells at least partially by neutralisation of viral infectivity [75]. In vitro study 
demonstrated that CyHV-3 inhibits activity of stimulated macrophages and proliferative response of lymphocytes and that this effect is temperature dependent [99].

\subsubsection{Interferon type I response}

Interferons (IFNs) are secreted mediators that play essential roles in the innate immune response against viruses. In vitro studies demonstrated that CyHV-3 inhibits IFN type I secretion in CCB cells [100]. Poly I:C stimulation of CCB cells prior to CyHV-3 infection activated the IFN type I response and reduced CyHV-3 spreading in the cell culture [100]. In vivo studies showed that CyHV-3 induced a systemic IFN type I response in carp skin and intestine and that the magnitude of IFN type I expression is correlated with the virus load $[60,98]$.

Recently, Tomé et al. demonstrated that CyHV-3 ORF112 encodes a new Z-domain family protein which in vitro showed structural and functional properties similar to the poxvirus E3L inhibitor of interferon response [101]. This suggested that CyHV-3 may use similar mechanisms to inhibit interferon response as poxviruses. However, the potential function of ORF112 in virus pathogenesis in vivo has not been studied yet.

\subsubsection{The role of CyHV-3 IL-10 homologue}

CyHV-3 ORF134 encodes a viral homologue of cellular IL-10 [18]. Its expression product is a 179 amino acid protein [102]. Common carp IL-10 and CyHV-3 IL-10 exhibit $26.9 \%$ identity (67.3\% similarity) over a 156 amino acid overlap [103]. Transcriptomic analyses revealed that ORF134 is expressed as a spliced gene belonging to the early [37] or early-late class [31]. Proteomic analyses of CyHV-3 infected cell supernatant demonstrated that ORF134 expression product is one of the most abundant proteins of the CyHV-3 secretome [31]. In CyHV-3 infected carp, ORF134 is highly expressed during acute and reactivation phase, while is expressed on a low level during low-temperature induced persistent phase [102]. In vivo study using a zebrafish embryo model suggested that CyHV-3 ORF134 encodes a functional IL-10 homologue [102]. Injection of mRNA encoding CyHV-3 IL-10 into zebrafish embryos increased the number of lysozymepositive cells to a similar degree as observed with zebrafish IL-10 [102]. Moreover, down-regulation of the IL-10 receptor long chain (IL-10R1) using a specific morpholino abrogated the increase of the number of lysozyme-positive cells after co-injection with either CyHV-3 IL-10 mRNA or zebrafish IL-10 mRNA, indicating that it functions via the IL-10 receptor [102].

Recently, a CyHV-3 strain deleted for ORF134 and a derived revertant strain were produced using BAC cloning technologies [31]. The recombinant ORF134 deleted strain replicated in vitro comparably to the parental and the revertant strains. Infection of fish by immersion in water containing the virus induced comparable mortality for the three virus genotypes tested (wild type, deleted and revertant). Quantification of viral DNA by real time TaqMan PCR and analysis of carp cytokines expression by RT-qPCR at different times post-infection did not reveal any significant difference between the groups of fish infected with the three virus genotypes. Moreover, histological examination of infected fish did not reveal significant differences between fish infected with the three genotypes. Altogether, these results demonstrated that the IL-10 homologue encoded by CyHV-3 is essential neither for viral replication in vitro nor for virulence in vivo [31].

\section{Conclusions}

Since its first description in the late 1990s, CyHV-3 rapidly spread to different continents (Europa, Asia, North America, Africa) causing severe financial losses in the common carp and koi culture industries worldwide. In addition to its negative economical and societal impacts, CyHV-3 has also a negative environmental impact by affecting wild populations of carp. These reasons explain why CyHV-3 became rapidly a subject for applied science and is now listed as a notifiable disease by the OIE. In addition to its economic importance, recent studies demonstrated that CyHV-3 is also a very attractive and original subject of fundamental research: $(i)$ it is phylogenetically distant from the vast majority of herpesviruses that have been studied so far (the latter belong to the family Herpesviridae), thereby providing an original field of research. (ii) It can be studied in laboratories by infection of its natural host (homologous virus-host model). (iii) The sequence of its genome published recently revealed a fascinating virus with unique properties in the Herpesvirales, such as an extremely large genome $(295 \mathrm{~Kb})$, a high number of genes which are not homologous to known viral sequences, and genes that are normally found exclusively in the Poxviridae [18]. (iv) Importantly, the CyHV-3 genome revealed several genes encoding proteins potentially involved in immune evasion mechanisms. (v) Last but not least, the outcome of CyHV-3 infection is highly dependent on the temperature of the water in which the carp are maintained.

\section{Abbreviations}

AngHV-1: Anguillid herpesvirus 1; Au: Goldfish fin cell; BAC: Bacterial artificial chromosome; CaF-2: Carp fin cell; CCB: Cyprinus carpio brain cell;

CCG: Cyprinus carpio gill cell; CNGV: Carp interstitial nephritis and gill necrosis virus; CPE: Cytopathic effect; CyHV-1: Cyprinid herpesvirus 1; CyHV-2: Cyprinid herpesvirus 2; CyHV-3: Cyprinid herpesvirus 3; dUTPase: Deoxyuridine

triphosphate pyrophosphatase; FHM: Fathead minnow cell; iNOS: Inducible nitric oxide synthase; IFNs: Interferons; IL-1 $\beta$ : Interleukin 1 $\beta$; IL-10: Interleukin 10; KFC: Koi fin cell; KF-1: Koi fin cell; KHV: Koi herpesvirus; KHVD: Koi herpesvirus disease; LUC: Luciferase; MHC class II B: Major histocompatibility complex class II $B$; NGF-2 and NGF-3: Epithelial-like cell line from fins of coloured carp (2 and 3); ORF: Open reading frame; TK: Thymidine kinase; TNFR: Tumor necrosis factor receptor; Tol/FL: Silver carp fin cell;

VNTR: Variable number of tandem repeats; 2D-LC MS/MS: Two-dimensional liquid chromatography tandem mass spectrometry. 


\section{Competing interests}

Dr Vanderplasschen's group is developing vaccine candidates against CyHV-3 as well as reagents to diagnose the disease.

\section{Authors' contributions}

$\mathrm{KR}, \mathrm{PO}$, and $\mathrm{AV}$ contributed to the design of the structure of the manuscript. $K R$ and $A V$ drafted the manuscript. KR, PO, MB, MR, AR, CV, JJ-R, and AV performed the overview of the literature on $\mathrm{CyHV}-3$, read and approved the final manuscript.

\section{Acknowledgments}

PO is a research fellow of the Chinese Scholarship Council. This work was supported by a grant from the University of Liège (Postdoc-IN program) and by grants of the "Fonds National Belge de la Recherche Scientifique" (FNRS) (R.FNRS.2165, -2697). KR and AV are members of the BELVIR consortium (IAP, phase VII) granted by the Belgian Science Policy Office (BELSPO) (Belgium).

Received: 25 July 2013 Accepted: 3 September 2013

Published: 27 September 2013

\section{References}

1. Balon EK: Origin and domestication of the wild carp, Cyprinus carpio: from Roman gourmets to the swimming flowers. Aquaculture 1995, 129:3-48.

2. Statistics and Information Service of the Fisheries and Aquaculture Department: Fishery and Aquaculture Statistics 2010. Rome: FAO; 2012.

3. Balon EK: The oldest domesticated fishes, and the consequences of an epigenetic dichotomy in fish culture. J Ichthyol Aquat Biol 2006, 11:47-86.

4. Magel GD, Tyring S: Herpesviridae- a look into this unique family of viruses. Shanghai: inTech; 2012

5. Wolf K, Darlington RW: Channel catfish virus: a new herpesvirus of ictalurid fish. J Virol 1971, 8:525-533.

6. Hedrick RP, McDowell TS, Groff JM, Yun S, Wingfield WH: Isolation of an epitheliotropic herpesvirus from white sturgeon Acipenser transmontanus. Dis Aquat Organ 1991, 11:49-56.

7. Haenen OLM, Dijkstra SG, Van Tulden PW, Davidse A, Van Nieuwstadt AP, Wagenaar F, Wellenberg GJ: Herpesvirus anguillae (HVA) isolations from disease outbreaks in cultured European eel, Anguilla anguilla in the Netherlands since 1996. Bull Eur Assoc Fish Pathol 2002, 22:247-257.

8. Bretzinger A, Fischer-Scherl T, Oumouna M, Hoffmann R, Truyen U: Mass mortalities in Koi carp, Cyprinus carpio, associated with gill and skin disease. Bull Eur Assoc Fish Pathol 1999, 19:182-185.

9. Hedrick RP, Gilad O, Yun S, Spangenberg J, Marty GD, Nordhausen RW Kebus M, Bercovier $\mathrm{H}$, Eldar A: A herpesvirus associated with mass mortality of juvenile and adult koi, a strain of common carp. J Aquat Anim Health 2000, 12:44-57.

10. Haenen OLM, Way K, Bergmann SM, Ariel E: The emergence of koi herpesvirus and its significance to European aquaculture. Bull Eur Assoc Fish Pathol 2004, 24:293-307.

11. Ronen A, Perelberg A, Abramowitz J, Hutoran M, Tinman S, Bejerano I, Steinitz M, Kotler M: Efficient vaccine against the virus causing a lethal disease in cultured Cyprinus carpio. Vaccine 2003, 21:4677-4684.

12. Waltzek TB, Kelley GO, Stone DM, Way K, Hanson L, Fukuda H, Hirono I, Aoki T, Davison AJ, Hedrick RP: Koi herpesvirus represents a third cyprinid herpesvirus (CyHV-3) in the family Herpesviridae. J Gen Virol 2005, 86:1659-1667.

13. Davison AJ, Kurobe T, Gatherer D, Cunningham C, Korf I, Fukuda H, Hedrick RP, Waltzek TB: Comparative genomics of carp herpesviruses. J Virol 2013, 87:2908-2922

14. Waltzek TB, Kelley GO, Alfaro ME, Kurobe T, Davison AJ, Hedrick RP: Phylogenetic relationships in the family Alloherpesviridae. Dis Aquat Organ 2009, 84:179-194.

15. Miyazaki T, Kuzuya Y, Yasumoto S, Yasuda M, Kobayashi T: Histopathological and ultrastructural features of Koi herpesvirus (KHV)infected carp Cyprinus carpio, and the morphology and morphogenesis of KHV. Dis Aquat Organ 2008, 80:1-11.

16. Miwa S, Ito T, Sano M: Morphogenesis of koi herpesvirus observed by electron microscopy. J Fish Dis 2007, 30:715-722.

17. Mettenleiter TC, Klupp BG, Granzow H: Herpesvirus assembly: an update. Virus Res 2009, 143:222-234.
18. Aoki T, Hirono I, Kurokawa K, Fukuda H, Nahary R, Eldar A, Davison AJ, Waltzek TB, Bercovier H, Hedrick RP: Genome sequences of three koi herpesvirus isolates representing the expanding distribution of an emerging disease threatening koi and common carp worldwide. J Virol 2007, 81:5058-5065.

19. Costes B, Fournier G, Michel B, Delforge C, Raj VS, Dewals B, Gillet L, Drion P, Body A, Schynts F, Lieffrig F, Vanderplasschen A: Cloning of the koi herpesvirus genome as an infectious bacterial artificial chromosome demonstrates that disruption of the thymidine kinase locus induces partial attenuation in Cyprinus carpio koi. J Virol 2008, 82:4955-4964.

20. Michel B, Leroy B, Stalin Raj V, Lieffrig F, Mast J, Wattiez R, Vanderplasschen $A F$, Costes $B$ : The genome of cyprinid herpesvirus 3 encodes 40 proteins incorporated in mature virions. J Gen Virol 2010, 91:452-462.

21. Van Beurden SJ, Bossers A, Voorbergen-Laarman MH, Haenen OL, Peters S, Abma-Henkens MH, Peeters BP, Rottier PJ, Engelsma MY: Complete genome sequence and taxonomic position of anguillid herpesvirus 1 . $J$ Gen Virol 2010, 91:880-887.

22. Michel B, Fournier G, Lieffrig F, Costes B, Vanderplasschen A: Cyprinid herpesvirus 3. Emerg Infect Dis 2010, 16:1835-1843.

23. Bigarré L, Baud M, Cabon J, Antychowicz J, Bergmann SM, Engelsma M, Pozet F, Reichert M, Castric J: Differentiation between Cyprinid herpesvirus type-3 lineages using duplex PCR. J Virol Methods 2009, 158:51-57.

24. Kurita J, Yuasa K, Ito T, Sano M, Hedrick RP, Engelsma MY, Haenen OLM, Sunarto A, Kholidin EB, Chou H-Y, Tung M-C, de la Peña L, Lio-Po G, Tu C, Way K, lida T: Molecular epidemiology of koi herpesvirus. Fish Pathol 2009, 44:59-66.

25. Sunarto A, McColl KA, Crane MS, Sumiati T, Hyatt AD, Barnes AC, Walker PJ: Isolation and characterization of koi herpesvirus (KHV) from Indonesia: identification of a new genetic lineage. J Fish Dis 2011, 34:87-101.

26. Avarre JC, Madeira JP, Santika A, Zainun Z, Baud M, Cabon J, Caruso D, Castric J, Bigarré L, Engelsma M, Maskur M: Investigation of Cyprinid herpesvirus-3 genetic diversity by a multi-locus variable number of tandem repeats analysis. J Virol Methods 2011, 173:320-327.

27. Dong C, Li X, Weng S, Xie S, He J: Emergence of fatal European genotype CyHV-3/KHV in mainland China. Vet Microbiol 2013, 162:239-244.

28. Han JE, Kim JH, Renault T, Choresca Jr. C, Shin SP, Jun JW, Park SC: Identifying the viral genes encoding envelope glycoproteins for differentiation of Cyprinid herpesvirus 3 isolates. Viruses 2013, 5:568-576.

29. Rosenkranz D, Klupp BG, Teifke JP, Granzow H, Fichtner D, Mettenleiter TC, Fuchs W: Identification of envelope protein pORF81 of koi herpesvirus. J Gen Virol 2008, 89:896-900.

30. Gotesman M, Soliman H, El-Matbouli M: Antibody screening identifies 78 putative host proteins involved in Cyprinid herpesvirus 3 infection or propagation in common carp, Cyprinus carpio L. J Fish Dis 2013, 36:721-733.

31. Ouyang P, Rakus K, Boutier M, Reschner A, Leroy B, Ronsmans M, Fournier G, Scohy S, Costes B, Wattiez R, Vanderplasschen A: The IL-10 homologue encoded by cyprinid herpesvirus 3 is essential neither for viral replication in vitro nor for virulence in vivo. Vet Res 2013, 44:53.

32. Neukirch $M$, Böttcher $K$, Bunnajirakul $S$ : Isolation of a virus from koi with altered gills. Bull Eur Assoc Fish Pathol 1999, 19:221-224.

33. Neukirch $\mathrm{M}, \mathrm{Kunz} \mathrm{U}$ : Isolation and preliminary characterization of several viruses from koi (Cyprinus carpio) suffering gill necrosis and mortality. Bull Eur Assoc Fish Pathol 2001, 21:125-135.

34. Dong C, Weng S, Li W, Li X, Yi Y, Liang Q, He J: Characterization of a new cell line from caudal fin of koi, Cyprinus carpio koi, and first isolation of cyprinid herpesvirus 3 in China. Virus Res 2011, 161:140-149.

35. Davidovich M, Dishon A, llouze M, Kotler M: Susceptibility of cyprinid cultured cells to cyprinid herpesvirus 3. Arch Virol 2007, 152:1541-1546.

36. Oh MJ, Jung SJ, Choi TJ, Kim HR, Rajendran KV, Kim YJ, Park MA, Chun SK: A viral disease occurring in cultured carp Cyprinus carpio in Korea. Fish Pathol 2001, 36:147-151.

37. Ilouze M, Dishon A, Kotler M: Coordinated and sequential transcription of the cyprinid herpesvirus-3 annotated genes. Virus Res 2012, 169:98-106.

38. Fuchs W, Fichtner D, Bergmann SM, Mettenleiter TC: Generation and characterization of koi herpesvirus recombinants lacking viral enzymes of nucleotide metabolism. Arch Virol 2011, 156:1059-1063.

39. Le Morvan C, Troutaud D, Deschaux P: Differential effects of temperature on specific and nonspecific immune defences in fish. J Exp Biol 1998, 201:165-168.

40. Dishon A, Davidovich M, llouze M, Kotler M: Persistence of cyprinid herpesvirus 3 in infected cultured carp cells. J Virol 2007, 81:4828-4836.

41. Ilouze M, Dishon A, Kotler M: Down-regulation of the cyprinid herpesvirus- 3 annotated genes in cultured cells maintained at restrictive high temperature. Virus Res 2012, 169:289-295. 
42. Gilad O, Yun S, Zagmutt-Vergara FJ, Leutenegger CM, Bercovier H, Hedrick RP: Concentrations of a Koi herpesvirus (KHV) in tissues of experimentally infected Cyprinus carpio koi as assessed by real-time TaqMan PCR. Dis Aquat Organ 2004, 60:179-187.

43. St-Hilaire S, Beevers N, Way K, Le Deuff RM, Martin P, Joiner C: Reactivation of koi herpesvirus infections in common carp Cyprinus carpio. Dis Aquat Organ 2005, 67:15-23.

44. St-Hilaire $S$, Beevers $N$, Joiner $C_{1}$ Hedrick RP, Way K: Antibody response of two populations of common carp, Cyprinus carpio L., exposed to koi herpesvirus. J Fish Dis 2009, 32:311-320.

45. Yuasa K, Ito T, Sano M: Effect of water temperature on mortality and virus shedding in carp experimentally infected with koi herpesvirus. Fish Pathol 2008, 43:83-85.

46. Uchii K, Matsui K, lida T, Kawabata Z: Distribution of the introduced cyprinid herpesvirus 3 in a wild population of common carp, Cyprinus carpio L. J Fish Dis 2009, 32:857-864.

47. Denham KL: Koi herpesvirus in wild fish. Vet Rec 2003, 153:507.

48. Terhune JS, Grizzle JM, Hayden K, McClenahan SD, Lamprecht SD, White MG: First report of koi herpesvirus in wild common carp in the western hemisphere. Fish Health Newsletter 2004, 32:8-9.

49. Grimmett SG, Warg JV, Getchell RG, Johnson DJ, Bowser PR: An unusual koi herpesvirus associated with a mortality event of common carp Cyprinus carpio in New York State, USA. J Wildl Dis 2006, 42:658-662.

50. Garver KA, Al-Hussinee L, Hawley LM, Schroeder T, Edes S, LePage V, Contador E, Russell S, Lord S, Stevenson RM, Souter B, Wright E, Lumsden JS: Mass mortality associated with koi herpesvirus in wild common carp in Canada. J Wildl Dis 2010, 46:1242-1251.

51. Minamoto T, Honjo MN, Uchii K, Yamanaka H, Suzuki AA, Kohmatsu Y, lida T, Kawabata Z: Detection of cyprinid herpesvirus 3 DNA in river water during and after an outbreak. Vet Microbio/ 2009, 135:261-266.

52. Minamoto T, Honjo MN, Yamanaka H, Uchii K, Kawabata Z: Nationwide Cyprinid herpesvirus 3 contamination in natural rivers of Japan. Res Vet Sci 2012, 93:508-514.

53. Honjo MN, Minamoto T, Kawabata Z: Reservoirs of Cyprinid herpesvirus 3 (CyHV-3) DNA in sediments of natural lakes and ponds. Vet Microbiol 2012, 155:183-190

54. Kielpinski M, Kempter J, Panicz R, Sadowski J, Schütze H, Ohlemeyer S, Bergmann SM: Detection of KHV in freshwater mussels and Crustaceans from ponds with KHV history in Common Carp (Cyprinus carpio). Isr J Aquac Bamidgeh 2010, 62:28-37.

55. Bergmann SM, Sadowski J, Kielpinski M, Bartlomiejczyk M, Fichtner D, Riebe $R$, Lenk $M$, Kempter J: Susceptibility of koi $x$ crucian carp and koi $x$ goldfish hybrids to koi herpesvirus (KHV) and the development of KHV disease (KHVD). J Fish Dis 2010, 33:267-272.

56. Rakus KL, Wiegertjes GF, Adamek M, Siwicki AK, Lepa A, Irnazarow I: Resistance of common carp (Cyprinus carpio L.) to Cyprinid herpesvirus-3 is influenced by major histocompatibility $(\mathrm{MH})$ class II B gene polymorphism. Fish Shellfish Immunol 2009, 26:737-743.

57. Fournier G, Boutier M, Stalin Raj V, Mast J, Parmentier E, Vanderwalle $P$, Peeters D, Lieffrig F, Farnir F, Gillet L, Vanderplasschen A: Feeding Cyprinus carpio with infectious materials mediates cyprinid herpesvirus 3 entry through infection of pharyngeal periodontal mucosa. Vet Res 2012, 43:6.

58. Perelberg A, Smirnov M, Hutoran M, Diamant A, Bejerano Y, Kotler M: Epidemiological description of a new viral disease afflicting cultured Cyprinus Carpio in Israel. Isr J Aquac Bamidgeh 2003, 55:5-12.

59. Pikarsky E, Ronen A, Abramowitz J, Levavi-Sivan B, Hutoran M, Shapira Y, Steinitz M, Perelberg A, Soffer D, Kotler M: Pathogenesis of acute viral disease induced in fish by carp interstitial nephritis and gill necrosis virus. J Virol 2004, 78:9544-9551.

60. Adamek M, Syakuri H, Harris S, Rakus KL, Brogden G, Matras M, Irnazarow I, Steinhagen D: Cyprinid herpesvirus 3 infection disrupts the skin barrier of common carp (Cyprinus carpio L.). Vet Microbiol 2013, 162:456-470.

61. Hedrick RP, Waltzek TB, McDowell TS: Susceptibility of koi carp, common carp, goldfish, and goldfish $\mathrm{x}$ common carp hybrids to cyprinid herpesvirus-2 and herpes virus-3. J Aquat Anim Health 2006, 18:26-34.

62. Bergmann SM, Schütze $H$, Fischer U, Fichtner D, Riechardt M, Meyer $K_{\text {, }}$ Schrudde D, Kempter J: Detection KHV genome in apparently health fish. Bull Eur Assoc Fish Pathol 2009, 29:145-152.

63. Kempter J, Bergmann SM: Detection of koi herpesvirus (KHV) genome in wild and farmed fish from Northern Poland. Aquaculture 2007, 272:S275-S275.

64. Kempter J, Kielpinski M, Panicz R, Sadowski J, Mysłowski B, Bergmann SM: Horizontal transmission of koi herpes virus (KHV) from potential vector species to common carp. Bull Eur Assoc Fish Pathol 2012, 32:212-219.
65. Fabian M, Baumer A, Steinhagen D: Do wild fish species contribute to the transmission of koi herpesvirus to carp in hatchery ponds? J Fish Dis 2012, 36:505-514.

66. Kempter J, Sadowski J, Schütze H, Fischer U, Dauber M, Fichtner D, Panicz R, Bergmann SM: Koi herpes virus: do acipenserid restitution programs pose a threat to carp farms in the disease-free zones? Acta Ichthyol Piscat 2009, 39:119-126.

67. El-Matbouli M, Saleh M, Soliman H: Detection of cyprinid herpesvirus type 3 in goldfish cohabiting with CyHV-3-infected koi carp (Cyprinus carpio koi). Vet Rec 2007, 161:792-793.

68. El-Matbouli M, Soliman H: Transmission of Cyprinid herpesvirus-3 (CyHV-3) from goldfish to naive common carp by cohabitation. Res Vet Sci 2011, 90:536-539.

69. Bergmann SM, Lutze P, Schütze H, Fischer U, Dauber M, Fichtner D, Kempter J: Goldfish (Carassius auratus auratus) is a susceptible species for koi herpesvirus (KHV) but not for KHV disease (KHVD). Bull Eur Assoc Fish Pathol 2010, 30:74-84.

70. Radosavljević V, Jeremić S, Ćirković M, Lako B, Milićević V, Potkonjak A, Nikolin V: Common fish species in polyculture with carp as cyprinid herpes virus 3 carriers. Acta Vet 2012, 62:675-681.

71. OIE (World Organisation for Animal Health): Report of the meeting of the OIE aquatic animal health standards commission. Paris; 2012. [http://www.oie.int/ fileadmin/Home/eng/Internationa_Standard_Setting/docs/pdf/ Aquatic_Commission/A_AAC_March_2012.pdf]

72. Ito T, Sano M, Kurita J, Yuasa K, lida T: Carp larvae are not susceptible to Koi Herpesvirus. Fish Pathol 2007, 42:107-109.

73. Ronsmans M, Rougeot C, Melard C, Vanderplasschen A: Susceptibility of Cyprinus carpio to Cyprinid herpesvirus-3 at the early stages of life. The Netherlands: Fish Immunology Workshop, Wageningen; 2012.

74. Costes B, Raj VS, Michel B, Fournier G, Thirion M, Gillet L, Mast J, Lieffrig F, Bremont M, Vanderplasschen A: The major portal of entry of koi herpesvirus in Cyprinus carpio is the skin. J Virol 2009, 83:2819-2830.

75. Raj VS, Fournier G, Rakus K, Ronsmans M, Ouyang P, Michel B, Delforges C, Costes B, Farnir F, Leroy B, Wattiez R, Melard C, Mast J, Lieffrig F, Vanderplasschen A: Skin mucus of Cyprinus carpio inhibits cyprinid herpesvirus 3 binding to epidermal cells. Vet Res 2011, 42:92.

76. Eide K, Miller-Morgan T, Heidel J, Bildfell R, Jin L: Results of total DNA measurement in koi tissue by Koi Herpesvirus real-time PCR. J Virol Methods 2011, 172:81-84.

77. Yuasa K, Sano M: Koi herpesvirus: status of outbreaks, diagnosis, surveillance, and research. Isr J Aquac Bamidgeh 2009, 61:169-179.

78. Bergmann SM, Kempter J: Detection of koi herpesvirus (KHV) after reactivation in persistently infected common carp (Cyprinus carpio L.) using non-lethal sampling methods. Bull Eur Assoc Fish Pathol 2011, 31:92-100.

79. Eide KE, Miller-Morgan T, Heidel JR, Kent ML, Bildfell RJ, LaPatra S, Watson G, Jin L: Investigation of koi herpesvirus latency in koi. J Virol 2011, 85:4954-4962.

80. Xu JR, Bently J, Beck L, Reed A, Miller-Morgan T, Heidel JR, Kent ML, Rockey $D D$, Jin L: Analysis of koi herpesvirus latency in wild common carp and ornamental koi in Oregon, USA. J Virol Methods 2013, 187:372-379.

81. Dishon A, Perelberg A, Bishara-Shieban J, Ilouze M, Davidovich M, Werker S, Kotler M: Detection of carp interstitial nephritis and gill necrosis virus in fish droppings. Appl Environ Microbiol 2005, 71:7285-7291.

82. Minamoto T, Honjo MN, Yamanaka H, Tanaka N, Itayama T, Kawabata Z: Detection of cyprinid herpesvirus-3 DNA in lake plankton. Res Vet Sci 2011, 90:530-532.

83. Ilouze M, Davidovich M, Diamant A, Kotler M, Dishon A: The outbreak of carp disease caused by CyHV-3 as a model for new emerging viral diseases in aquaculture: a review. Ecol Res 2011, 26:885-892.

84. Shimizu T, Yoshida N, Kasai H, Yoshimizu M: Survival of koi herpesvirus (KHV) in environmental water. Fish Pathol 2006, 41:153-157.

85. Honjo MN, Minamoto T, Matsui K, Uchii K, Yamanaka H, Suzuki AA, Kohmatsu Y, lida T, Kawabata Z: Quantification of cyprinid herpesvirus 3 in environmental water by using an external standard virus. Appl Environ Microbiol 2010, 76:161-168.

86. Yuasa K, Kurita J, Kawana M, Kiryu I, Oseko N, Sano M: Development of mRNA-specific RT-PCR for the detection of koi herpesvirus (KHV) replication stage. Dis Aquat Organ 2012, 100:11-18.

87. Aoki T, Takano T, Unajak S, Takagi M, Kim YR, Park SB, Kondo H, Hirono I, Saito-Taki T, Hikima J, Jung TS: Generation of monoclonal antibodies 
specific for ORF68 of koi herpesvirus. Comp Immunol Microbiol Infect Dis 2011, 34:209-216.

88. Vrancken R, Boutier M, Ronsmans M, Reschner A, Leclipteux T, Lieffrig F, Collard A, Mélard C, Wera S, Neyts J, Goris N, Vanderplasschen A: Laboratory validation of a lateral flow device for the detection of CyHV-3 antigens in gill swabs. J Virol Methods 2013, 193:679-682.

89. Perelberg A, Ronen A, Hutoran M, Smith Y, Kotler M: Protection of cultured Cyprinus carpio against a lethal viral disease by an attenuated virus vaccine. Vaccine 2005, 23:3396-3403.

90. Israel: KoVax Ltd. [http://www.kovax.co.il/products/kv3-vaccine-against-khv/]

91. Perelberg A, llouze M, Kotler M, Steinitz M: Antibody response and resistance of Cyprinus carpio immunized with cyprinid herpes virus 3 (CyHV-3). Vaccine 2008, 26:3750-3756

92. Yasumoto S, Kuzuya Y, Yasuda M, Yoshimura T, Miyazaki T: Oral immunization of common carp with a liposome vaccine fusing Koi herpesvirus antigen. Fish Pathol 2006, 41:141-145.

93. Shapira $Y$, Magen $Y$, Zak T, Kotler M, Hulata G, Levavi-Sivan B: Differential resistance to koi herpes virus (KHV)/carp interstitial nephritis and gill necrosis virus (CNGV) among common carp (Cyprinus carpio L.) strains and crossbreds. Aquaculture 2005, 245:1-11.

94. Piackova V, Flajshans M, Pokorova D, Reschova S, Gela D, Cizek A, Vesely T: Sensitivity of common carp, Cyprinus carpio L., strains and crossbreeds reared in the Czech Republic to infection by cyprinid herpesvirus 3 (CyHV-3; KHV). J Fish Dis 2013, 36:75-80.

95. Dixon PF, Joiner CL, Way K, Reese RA, Jeney G, Jeney Z: Comparison of the resistance of selected families of common carp, Cyprinus carpio L., to koi herpesvirus: preliminary study. J Fish Dis 2009, 32:1035-1039.

96. Kongchum P, Sandel E, Lutzky S, Hallerman EM, Hulata G, David L, Palti Y: Association between IL-10a single nucleotide polymorphisms and resistance to cyprinid herpesvirus-3 infection in common carp (Cyprinus carpio). Aquaculture 2011, 315:417-421.

97. Rakus KL, Irnazarow I, Adamek M, Palmeira L, Kawana Y, Hirono I, Kondo H, Matras M, Steinhagen D, Flasz B, Brogden G, Vanderplasschen A, Aoki T: Gene expression analysis of common carp (Cyprinus carpio L.) lines during Cyprinid herpesvirus 3 infection yields insights into differential immune responses. Dev Comp Immunol 2012, 37:65-76.

98. Syakuri H, Adamek M, Brogden G, Rakus KL, Matras M, Irnazarow I, Steinhagen D: Intestinal barrier of carp (Cyprinus carpio L.) during a cyprinid herpesvirus 3-infection: Molecular identification and regulation of the mRNA expression of claudin encoding genes. Fish Shellfish Immunol 2013, 34:305-314.

99. Siwicki A, Kazuń K, Kazuń B, Majewicz-Zbikowska E: Impact of cyprinid herpesvirus-3, which causes interstitial nephritis and gill necrosis, on the activity of carp (Cyprinus carpio L.) macrophages and lymphocytes. Arch Pol Fish 2012, 20:123-128.

100. Adamek M, Rakus KL, Chyb J, Brogden G, Huebner A, Irnazarow I, Steinhagen D: Interferon type I responses to virus infections in carp cells: In vitro studies on Cyprinid herpesvirus 3 and Rhabdovirus carpio infections. Fish Shellfish Immunol 2012, 33:482-493.

101. Tomé AR, Kuś K, Correia S, Paulo LM, Zacarias $S$, de Rosa M, Figueiredo D, Parkhouse RM, Athanasiadis A: Crystal structure of a poxvirus-like zalpha domain from cyprinid herpesvirus 3. J Virol 2013, 87:3998-4004.

102. Sunarto A, Liongue C, McColl KA, Adams MM, Bulach D, Crane MSJ, Schat KA, Slobedman B, Barnes AC, Ward AC, Walker PJ: Koi herpesvirus encodes and expresses a functional interleukin-10. J Virol 2012, 86:11512-11520.

103. Van Beurden SJ, Forlenza M, Westphal AH, Wiegertjes GF, Haenen OL, Engelsma MY: The alloherpesviral counterparts of interleukin 10 in European eel and common carp. Fish Shellfish Immunol 2011, $31: 1211-1217$

doi:10.1186/1297-9716-44-85

Cite this article as: Rakus et al:: Cyprinid herpesvirus 3: an interesting virus for applied and fundamental research. Veterinary Research 2013 44:85

\section{Submit your next manuscript to BioMed Central and take full advantage of:}

- Convenient online submission

- Thorough peer review

- No space constraints or color figure charges

- Immediate publication on acceptance

- Inclusion in PubMed, CAS, Scopus and Google Scholar

- Research which is freely available for redistribution

Submit your manuscript at www.biomedcentral.com/submit
C Biomed Central 